\title{
About a Manuscript on Tea Found in Timbuktu, Mali: Mamma Haidara Collection, MS 125, Tārīkh al-shāy fĩ 'l-Maghrib
}

\begin{abstract}
This article reflects on the simultaneity of manuscript and print cultures in Northwest Africa and the relationship between them, challenging the conventional idea of progress from one form of textual reproduction to another. In particular, the article examines the movement between print and manuscript worlds as reflected in a text, which was discovered in a Timbuktu collection, about the subject of tea. In addition to appealing to this particular text as an invitation to future work on the relationship between the two processes of storing the written word, the article illustrates the possibility of using the collections in Timbuktu to write about the history of consumable goods.
\end{abstract}

\section{Introduction}

Tea is now widely consumed in the Maghrib and large parts of West Africa, and one thinks especially of Mauritania, Senegal, Mali, and Niger in this regard. The extensive daily consumption of tea might seem like a thousand-year-old tradition with local roots. As historical research has shown, however, tea arrived relatively recently - sometime during the eighteenth century - with the expansion of European merchant capitalism and the increasing incorporation of Northwest Africa into this commerce. In some parts of urban West Africa, the widespread use of tea began only in the post-Independence period and has increased since the turn of this century, when tea began to arrive directly through an expansive network of small traders from mainland China.

On one of my exploratory trips to Timbuktu in the early 2000s, I was told about a text that had the terms 'history' and 'tea' in its title. Our project was allowed to make images of this manuscript, which was quite a rarity at the time, and the digital copy made then is the basis for this article. ${ }^{1}$ This manuscript, Timbuktu, Mamma Haidara Collection, MS 125 (1,71), Tārīkh al-shāy fí 'l-Maghrib

1 It does reflect some confidence in me, my team, and our work on the materials at Timbuktu that we were allowed to make a digital copy of the manuscript. 
تاريخ الثاي في المغرب, has seven folios. The cover page gives the item number and the title (reproduced in the title of this essay) and reports the dimensions of the paper without indicating the units of measurement $(13.5 \times 20.9$ for the cover and $9.9 \times 18.3$ for the manuscript itself). I did not encounter the catalogue entry for this work until much later. It conforms to the details on the cover page and as part of the text, right at the end, reports the name of the author as Ibn 'Ișām al-Ribātī and the number of folios (al-awrāq) as four (04). ${ }^{2}$

In many of the manuscripts in the field, or in the catalogues of the Timbuktu collections, no composition or copying dates are recorded. It is often impossible to determine when a text was first written or when it was copied. The paper is, of course, revealing, and this particular text is on paper that was once lined but is now faded, which indicates that the paper is modern, a twentieth century product. But the date of the paper might just tell us when a copy of the work was made; the work itself might have been written at an earlier date. A copy could have been a means of conserving a work whose paper was disintegrating or whose text was becoming illegible, but there could be, of course, multiple other reasons why a copy of this work was made. So this manuscript on fading, factory-made, lined paper probably from a French mass-market paper manufacturer, could have reached Timbuktu anytime during the twentieth century. The apparent absence of a date or author's name initially led me to believe that the manuscript was copied from another source, rather than being an original composition. I shall return to the dating of the manuscript and the work later in the article.

As indicated above, I was eventually able to identify this item in the Mamma Haidara catalogue, which had then recently been published. ${ }^{3}$ This manuscript is unusual in the existing catalogues of Timbuktu collections, which list large numbers of works that deal with law and grammar, poetry and legal opinions, and other normative subjects. These catalogues do not, I believe, reflect the actual holdings of the collections. The coverage of the catalogues is rather due to a decision made by their sponsor-publisher and by others who were involved in the publication of the catalogues. Some limit had to be set on what could be included, so a version of the classical Islamic corpus in the local iteration of Timbuktu was decided upon. ${ }^{4}$ Based on numerous visits to many different family collections there, which into recent times were and probably still remain uncatalogued and unstudied, I have the impression that such collections

2 Mammā Ḥaydara 2000, vol. 1, 71 (item no. 125).

3 Mammā Ḥaydara 2000.

4 Hall and Stewart 2011; Jeppie 2017. 
contain a greater variety of materials than is reflected in their listings, especially the published ones. ${ }^{5}$

Such were the limitations of the tools at the beginning of this century. The intervening decades have seen continuing efforts to improve the apparatuses for working with the manuscripts, albeit in highly unpredictable circumstances. Long periods of optimism, such as from the time when military rule ended in 1991 to the insurgency of 2011, have been followed by intense outbursts of instability, and we are still living through such a moment. So one has to work with what is available in such circumstances and subject to the limitations of time and funding. But even the 'normative Islamic' texts can, of course, be read for other kinds of information, such as social or gender history. ${ }^{6}$ However, to have found a manuscript that so explicitly falls into the field of social history is unique, especially when histories of consumption were coming into vogue. ${ }^{7}$

\section{Overview of the manuscript's contents}

What follows is not a translation of the text but a précis:

The inhabitants of the Maghrib are tea drinkers whether they live in cities or are nomads. They drink at all times of the day and also on special occasions. While tea is enjoyed in the Maghrib, it is in fact far from its place of origin in the East, that is, in China, India, and Russia, where there are millions more people.

According to the author, tea arrived in the Maghrib about a century and a half before his time. It first appeared in $1208 \mathrm{AH}$ (1789 CE), during the reign of Sultan Sīdī Muhammad bin 'Abdallāh. In Gibraltar there lived an English medical doctor, William Lempriere (in the manuscript written as follows: وليم لمبريير), who was well known for his expertise. ${ }^{8}$ The author cites a book by one Dr Bernard Louis (برنار لويز), but this is a rather generic name, and my searches have yielded no author who wrote anything of relevance to the Maghrib or about the history of tea.

5 The CSMC initiative in Bamako, currently still underway, might change this picture by showing that there are more works than simply what is required for a good Islamic education.

6 See, for instance, Mathee 2011.

7 Krieger 2009; Schivelbusch 1992.

8 William Lempriere (d. 1834) was the author of, among other works, A Tour from Gibraltar to Tangier (1791 and subsequent editions) in which he described his activity as a medical doctor to the Moroccan Sultan and his household. Lempriere encountered tea-drinking there and did not himself introduce it. 
When the Sultan, who had a sick son, was in Marrakesh, he invited William Lempriere to come and look at the state of his son's health. The doctor had a supply of tea with him which gave him the energy to work tirelessly. The Sultan was initially hesitant about the legality of this drink but allowed its use as a medication. 'Ulamā' were also consulted about the drink's permissibility. When the son's health improved, a celebration was held and tea was served. Since that time tea became famous, first inside the court and then outside among all classes.

The English, Portuguese, and Dutch merchants who had long-established trade relations with China and India supplied tea to the Maghrib. Sugar was supplied by traders from Germany, Austria, and France.

In conclusion, the author asks, did the Maghrib know the mint plant before the arrival of tea? Nowhere else is mint mixed with tea, which has tremendous health benefits. This is where the manuscript comes to an end.

There is no point in attempting to correct any of the information in this work. There was indeed such a visitor as William Lempriere who wrote a travelogue and met the Sultan and his family and acted as their medical doctor during his visit. Lempriere encountered tea-drinking there, but he did not himself introduce tea to his hosts. In the travelogue, Lempriere gives some impression of the ritual of taking tea - sitting for at least two hours when taking it, for instance - and he briefly describes the arrangement of the teacups on a little table during the ritual. According to Lempriere, tea was always taken with mint and plenty of sugar. Being served tea is 'the highest compliment that can be offered by a Moor; for tea is a very expensive and scarce article in Barbary, and it is only drank by the rich and luxurious. ${ }^{9}$ The author of the work transmitted in our manuscript, however, could not have read the book of Lempriere. Instead our author probably heard about Lempriere and his book through an oral tradition that gave such a version of the English doctor's sojourn.

\section{From manuscript to print and back again}

When I returned to the tea manuscript much later, I realised that there was a missing folio; once I found it among our collection of images, I read what amounted to a colophon that was probably added later:

9 Lempriere 1804, 212. 
This history of the first appearance of tea in the Maghrib was taken from the newspaper Al-Sa'āda, which was published in Ribāt al-fätih (Rabat), as no. 8.096; Saturday Jumādā al-akhira 1370, corresponding to 10 March 1951; and the newspaper is 48 years old. ${ }^{10}$

In this reproduction of the title, the word 'tea' is spelled al-tāy not al-shāy, reflecting the local pronunciation.

This manuscript was therefore copied from a newspaper. A Moroccan broadsheet (four sheets in total) arrived in Timbuktu, and at least this article was reproduced from it. The article covers less than half of page two. The title page is devoted to reportage on Moroccan and world politics; then follow two pages of cultural topics, including this article on tea. Beside the article on tea is an article on poetry and a short story by the Egyptian writer 'Abd al-Qādir al-Māzinī. The piece on tea was not 'plagiarized', inasmuch as the article bears the name of its presumably Rabat-based author (al-Ribātī). Although the manuscript gives full details about its source, this information is not reproduced in the catalogue. Unfortunately, the copyist left no signature, and we do not know if the copy was commissioned or why it was undertaken, apart from the seemingly interesting narrative about a significant item of daily consumption. Whether the person responsible for this manuscript copied the newspaper article within the same month or year that it appeared, or did so many years later, remains unanswerable.

Instead of dismissing the manuscript because of its sheer lack of originality, we ought to consider that as a handwritten, that is, manual (not mechanical) reproduction the manuscript points to the significance of the article's subject. But the manuscript has larger implications too. Walter Benjamin's insight, to summarise all too briefly here, that with mechanical reproduction (such as lithography and printing) an art object loses an aura that it had when and where it was created, is pertinent. His famous essay deals mainly with the rising prevalence of photography and especially film as media, but it opens with a more general discussion of 'mechanical reproduction'. In our example, however, an aura was possibly bestowed precisely through manual reproduction; in a way, the reproduction became an 'original'. If not at the time then certainly in the years to come, as this and other manuscripts were re-encountered and rediscovered, there was an emanation of a kind of mystery around them. ${ }^{11} \mathrm{~A}$

10 Al-Sa‘āda: jarīda yawmiyya 'akhbāriyya السعادة: جريدة يومية أخبارية, 10 Māris 1951 (1 Jumādā 'l-akhīra 1370).

11 'Man kann diese Merkmale im Begriff der Aura zusammenfassen und sagen: Was im Zeitalter der technischen Reproduzierbarkeit des Kunstwerks verkümmert, das ist seine Aura' (Benjamin 1989, 353). 
further and equally important implication is that this move from print to manuscript goes against the grain of the standard narratives about the inevitability of texts moving from the handwritten to the printed word. Was it a unique case, or can we find other examples from the region of published materials being turned into manuscripts?

Printing arrived in Morocco during the 1860s amidst some ambivalence about it from the Sultan. There is evidence that there was even outright objection to it from the rulers. ${ }^{12}$ But when materials began to be produced and printing became legal, its acceptance quickly spread. The earliest newspapers appeared in the early nineteenth century and were issued by Spanish and French interests; Arabic newspapers began to appear only in the late 1880s. By the 1950s, Morocco had a range of newspapers in French and Arabic, with nationalist parties having their own newspapers despite the protectorate officials' attempts at limiting their production and circulation. $\mathrm{Al}-\mathrm{Sa} \mathbf{a}^{\prime} \bar{a} \mathrm{da}$, however, was an Arabic broadsheet positioned against the nationalist movement; it had started in Tangiers in 1904 with official funding from the French and with a proFrench editorial policy, and it ran until the end of $1956 .{ }^{13}$ It is worth noting that this French-backed newspaper is the source for the article that was copied in Timbuktu. Could it be that no other newspaper was allowed into the Frenchcontrolled territories even into the 1950s? The protectorate authorities did attempt to censor publications and monitor the circulation of printed materials by intercepting the mail and by other means. Printed materials arrived in Timbuktu soon after they began to be produced in Morocco. Materials that left the Moroccan protectorate for the neighbouring colonies to the south (Afrique-Occidentale française) were in all probability monitored by the colonial administration and its military and postal outposts in the territories, including at Timbuktu. Publications that entered French-controlled territory, especially works written in Arabic and directed at Muslims, were regularly recorded, along with descriptions of the works' assumed ideological orientation, and published in lists for the purpose of official monitoring. ${ }^{14}$ The colonial postal service conveyed newspapers, manuscripts, and books throughout the colonial and protectorate territo-

12 'Abd al-Razzāq 1990; for an Arabic version based on this thesis, see 'Abd al-Razzāq 1996.

$13 \mathrm{Al}$-Sa'āda ran from 1904 until 1956 as a pro-French mouthpiece, often with expatriate Lebanese editors. As such, it was probably allowed to circulate much more freely than other, independent newspapers which were critical of French rule.

14 See Aix-en-Provence, France, Archives nationale d'outre-mer, 19 G 24 \& 25, Contrôle des livres en Arabe. This is a list of Arabic newspapers and periodicals that came into Dakar and Bamako etc. between April and June of 1922. 
ries, which enabled it to keep an eye on the movement of materials through the postal system. ${ }^{15}$

\section{How tea reached Timbuktu, the Maghrib, and West Africa}

Tea consumption in the Maghrib, Sahara, and Sahel seems genuinely embedded in the habits and practices of town-dwellers such as those who lived in Timbuktu. That a manuscript such as this one should turn-up in a Timbuktu collection is thus a testimony to the acceptance, consumption, and value of tea. The history of tea-drinking in the region has been examined by various scholars, and they in turn have drawn on European travellers who observed the custom. ${ }^{16}$ While in the interior and amongst certain groups - such as the semi-nomadic 'Moors' mentioned by Lempriere - there is a long history of tea-drinking, elsewhere it is a recent practice. There was an opinion that tea travelled to the interior from the Atlantic coast, but there is little evidence in support of this theory. It is far more likely that the leaf came to Timbuktu from what is today Morocco. ${ }^{17}$ It remains to be seen how early we ought to date the arrival of tea; a thorough search through the Timbuktu collections might yield some clues. For instance, did somebody in Timbuktu or the surrounding region ask for a fatwa on the legality of tea from a scholar there? At this point we can only report that by the 1820s the French explorer René Caillié had already encountered tea-drinking, since he heads a section of a chapter relating to his reception in the town of Jenné as follows: 'Usage du thé, du sucre et de la porcelaine'. ${ }^{18}$

For the broader region, we can rely on the essay by Diawara and Röschenthaler, which covers the literature in European languages on the history of tea or tea varieties throughout the larger region, from Tangier to Timbuktu. ${ }^{19}$ The authors begin with an observation about the recent arrival of green tea in the Malian capital, Bamako, and in other towns in the country, though it had been used for far longer by the 'Moors' of the hinterlands, in the Sahara, and in

15 See, for instance, Dakar (Senegal), Direction des Archives du Sénégal, Série J, Postes et Télécommunications; versement no. 3 1911/1950. Serie O covers the period to 1911.

16 In the 1950s, there was an exchange among researchers on this subject; the literature is well covered in Diawara and Röschenthaler 2012.

17 Leriche 1951.

18 Caillié 1830, vol. 2, 223-224.

19 Diawara and Röschenthaler 2012. 
areas such as Timbuktu. Green tea became 'a common drink only in the last couple of decades', and this is partly due to the growth in direct imports from China. The authors allude to the cultivation of tea in Mali during the 1960s, but the product of this effort is seen as inferior to what is imported. The essay is intended as an ethnographic study of the consumption of a commodity and broadly supports the argument for a 'diffusion gradient' in which tea is first used by the aristocracy then filters down to other classes. For example, in the Maghrib tea was first used as a medicine, then as luxury, and then as a drink taken by virtually everyone. Sugar was also a luxury, used first in a large coneshaped form, then, when tea consumption spread, it was added to tea as granules or small cubes. Generally speaking, tea-drinking spread from city to countryside, but in this case the path led from the nomads through the countryside to city. The essay is a useful overview of the historical literature, and it sketches the outlines of the commercial networks that probably brought tea to the region. In addition, the article reports the words for 'tea' in the languages spoken there; the local words are all largely versions of the Chinese word for 'tea' transmitted through Arabic or French.

Any writing on the subject of tea in the Maghrib and adjoining territories cannot afford to ignore one work which is still only in Arabic; its title in translation would be From tea [shāy] to atāy: Custom and history. The title (من الثابي refers to the two different ways of saying 'tea': one with the letter shin and the other, more local and widespread in the region of Northwest Africa, with the letter $t \bar{a}$ ' (al-atāy), which is used, for example, in works written in the Berber language of Amazigh. This work, edited by two Moroccan scholars, 'Abd al-Aḥad al-Sabtī and 'Abd al-Raḥmān Lakhṣāṣī, ${ }^{20}$ is a major anthology that brings together a variety of genres of writing, including oral and song texts as well as a selection of images. The two scholars have compiled an impressive range of Arabic texts about tea from its earliest mention. Around 130 extracts of varying length are presented with brief introductions to each and full details on the sources. An extensive interpretive essay preceding the collection of sources periodises tea's presence in the Maghrib, its place in popular culture, and its relation to other beverages, particularly in more recent decades with the expansion of cold soft drinks.

The vast majority of the documentation pertains to the Maghrib and comes from the late eighteenth to end of the nineteenth centuries - since this is the period when tea consumption really spread.

20 Al-Sabtī and Lakhṣāṣī 2012. 
The anthology opens with the oldest-known Arabic text about tea, dating to $851 \mathrm{CE}$, by an unknown author. The first known Arabic author is al-Birūnī, who mentions tea in a work that dates to $1025 \mathrm{CE}$. Following the introduction, the anthology is organized in four sections: witnesses and reports, ornaments and accompaniments, benefits and harms, poetry and songs dealing with tea, with each section adopting a more or less chronological order. The sections contain extracts from traditional histories, chronicles, memoirs, travellers' reports by Europeans or Maghribis, archival sources, correspondence, and legal opinions (fatāwā) on the subject of tea.

Poetry in praise of tea is presented throughout, with numerous poems coming from various regions; some of the poems are quite short, such as a two-line poem against tea, while others are quite long, such as the early court poem written in 1746 by the physician of Sultan Ismail. Three extracts of poems from Mauritania are included. Poetry in Amazigh ('Berber') is translated into Arabic, and in such cases the original is given in the Appendix.

The Appendix also contains a series of documents the provide information about the importation of tea during the late nineteenth century; while the figures are revealing, even more so is the extensive list of tea merchants.

The indefatigable scholars who produced this trove of research did not include newspaper coverage of tea except for the odd advertisement and other images of tea-drinking from the press; so neither the al-Sa'a $\overline{d a}$ article nor, of course, its manuscript copy made in Timbuktu at an unknown date are included in the anthology.

Last but not least, there are manuscripts, mainly poetry, about tea in Timbuktu collections. According the catalogues of CEDRAB (Centre de documentation et de recherches Aḥmad Bābā, since renamed by the acronym Iheri-Ab), there were at least fifteen such poems in its holdings at the time of the publication of the relevant catalogues. For a fuller treatment of the subject, it will be necessary to examine all those manuscripts, bearing in mind some of the issues raised here. ${ }^{21}$

21 Catalogue of Ibn 'Āli et al. 1995-1998: Qașīda fi madḥ al-atāy (al-shāy) by Mawlūd b. Ahmādī; no. 934, vol. 1, 277; Manzūma fi madh al-atāy (al-shāy) - unknown; no. 922, vol. 2, 162; Manzūma fi madḥ al-atāy (al-shāy) - unknown; no. 2053, vol. 2, 208; Manzūma fi dhamm al-atāy (al-shāy) - Muhạmmad Ayyūb; no. 2267, vol.2, 284; Manzūma fi madḥ al-atāy (al-shāy) 'Uthmān b. al-Ḥājj b. Bello al-Anūkandrī; no.2327, vol.2, 304; Manzūma fi madḥ al-atāy (al-shāy) - Abūbakr b. Ḥammād al-Anūkandrī; no. 2332, vol. 2, 306; Manžūma fí madḥ al-atāy (al-shāy) - 'Abdullāh b. Aḥmad al-Sūqī; no. 2678, vol.2, 425; Manzūma fi madḥ al-atāy (al-shāy) - Maḥfūẓ b. Bay; no. 2762, vol. 2, 456; Qașīda fi madḥ al-atāy (al-shāy) wa sharḥuhā unknown; no. 3017, vol. 3, 17; Qaṣīda fi madḥ al-atāy (al-shāy) - 'Īsa b. Muḥammad b. al-Mawlūd 


\section{Conclusion}

Making copies was an integral part of the activities in a manuscript culture because there was no other way of material reproduction. Memorization was possible, but that was intangible and highly individual. A copy of a text could be shared and read and re-read and copied again. So a manuscript was produced by an author, and then there was the prospect of one or more copies - all handwritten and each reflecting an attempt at faithful representation of the original text as well as having its own idiosyncrasies. With the coming of print technologies to the places which had long and rich handwriting traditions, there was very often a struggle over the reception and use of this technology. In general the trend was that works moved from manuscript to print. Apart from the delightful subject of tea as a topic of writing, this essay raises the question of another possibility, the movement from print to manuscript. Is this a unique and rare case or was the practice more widespread in the region? More cases of this kind would be worth looking for.22

One approach to such material would be to dismiss print-to-manuscript texts as unoriginal and derivative. But this approach ignores a range of questions that might illumine attitudes towards print culture, and towards attempts to conserve the craft of manuscript copying, even as the seeming inevitability of print blows like Saharan sand through a tradition buries it in the past. There is no evidence of a Luddite reaction to the presence of printed works in Timbuktu and similar settings in the Sahara. Indeed there is evidence that print was accepted, at least among some involved in the manuscript world. Yet the manual production and reproduction of works persisted, and there are still a handful of practitioners of the craft; of course others can simply take the fruits of these practitioners' labour to the photocopier, and now anyone can just scan them with the ubiquitous cell phone.

b. Muhammad b. Abībakr b. al-Ṭālib; no. 3130, vol.3, 65; Qașīda fi madh al-atāy (al-shāy) unknown; no. 3206, vol.3, 99; Qașida fi hilya al-qahwa - unknown; no. 3208, vol. 3, 100; Qașīda fi hịlya al-atāy (al-shāy) - unknown; no. 3210, vol. 3, 101; Qașīda fi madḥ al-atāy (al-shāy) wa sharḥuhā - 'Īsa b. Muhammad b. al-Mawlūd b. Muhammad b. Abībakr b. al-Ṭālib; no. 3784, vol. 3, 341. With thanks to Ebrahim Moos for confirming items in the catalogues when I did not have access to them.

22 I would like to thank Mauro Nobili for reminding me of texts he has encountered that went from print to manuscript, including versions of the chronicle Tärikkh al-fattash. 


\section{References}

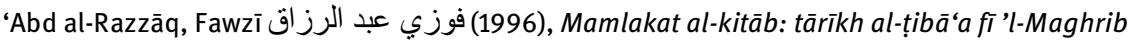
مملكة الكتاب: ناريخ الطباعة في المغرب (Mundus Arabicus, 6), Rabat: Publications de la Faculté des Lettres et des Sciences humaines.

Abdulrazaq, Fawzi (1990), The kingdom of the book: The history of printing as an agency of change in Morocco between 1865 and 1912, PhD thesis, Boston University.

Benjamin, Walter (1989), 'Das Kunstwerk im Zeitalter seiner technischen Reproduzierbarkeit (Zweite Fassung)', in Rolf Tiedemann and Hermann Schweppenhäuser (eds), Gesammelte Schriften, VII, I, Frankfurt am Main: Suhrkamp, 350-384 [1st edn: 1939].

Caillié, René (1830), Journal d'un voyage à Temboctou et à Jenné dans l'Afrique centrale, 2 vols, Paris : Imprimerie Royale.

Diawara, Mamadou and Ute Röschenthaler (2012), 'Green tea in the Sahel: The social history of an itinerant consumer good', Canadian Journal of African Studies, 46: 39-64.

Hall, Bruce S. and Charles C. Stewart (2011), 'The Historic “Core Curriculum" and the Book Market in Islamic West Africa', in Graizano Kratli and Ghislaine Lydon (eds), The TransSaharan Book Trade: Manuscript Culture, Arabic Literacy and Intellectual History in Muslim Africa (Library of the Written Word - The Manuscript World, 8), Leiden: Brill, 109-174.

Ibn 'Āli, Sīdī ‘Umar سيدي عمر بن علي (et al.) (1995-1998), Fihris makhṭūṭāt markaz Ahmad Bābā li-'l-tawthīk wa-'l-buhūth al-tārīkhiyya bi-Tinbuktū فهرس مخطوطات مركز احمد بابا للتوثيق و و البحوث التاريخية بتنبكتو 'Thols, London: Al-Furqan Islamic heritage foundation.

Jeppie, Shamil (2016) ‘Timbuktu Scholarship: But What Did They Read?', History of Humanities, 1: $213-229$.

Krieger, Martin (2009), Tee: eine Kulturgeschichte, Köln: Böhlau.

Lempriere, William (1804), A Tour from Gibraltar to Tangier, Sallee, Mogodore, Santa Cruz, and Tarudant; and thence over Mount Atlas to Morocco: Including a Particular Account of the Royal Harem, \&c, 3rd edn, London: Higham.

Leriche, Albert, (1951), 'L'origine du thé en Mauritanie', Bulletin de l'Institut Français d'Afrique Noire, 13: 866-871.

Mammā Ḥaydara, 'Abd al-Qādir عبد القادر ممّا حيدرة (2000), Fihris makhṭūtāt maktaba Mammā

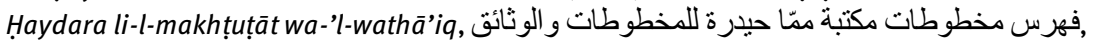
vol. 1, London: Al-Furqan Islamic heritage foundation.

Mathee, Mohamed Shaid (2011), Muftis and the women of Timbuktu: History through Timbuktu's Fatwās, 1907-1960, PhD thesis, University of Cape Town.

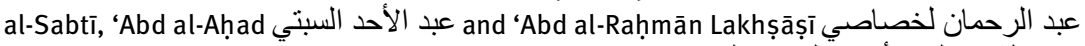

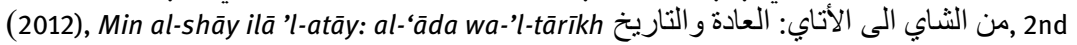
edn, Rabat: Publications de la Faculté des Lettres et des Sciences humaines.

Schivelbusch, Wolfgang (1992), Tastes of Paradise: A Social History of Spices, Stimulants, and Intoxicants, New York: Vintage Books. 
